BERETZKY ZSUZSANNA ${ }^{1}$

\title{
AZ INFORMÁliS ELLÁTÁS KÖLTSÉGE KRÓNIKUS BE- TEGSÉGEKBEN: MAGYARORSZÁGI KUTATÁSOK ÖSSZE- HASONLÍTÓ ELEMZÉSE \\ COST OF INFORMAL CARE IN CHRONIC DISEASES IN HuNgary: A COMPARATIVE ANALYSIS
}

Bevezetés: Magyarországon kevéssé ismertek az informális gondozás társadalmi terhei. Célkitüzés: Az informális ellátás költségeinek meghatározása krónikus betegségekben. Módszer: Tizenhárom korábbi hazai kutatás összehasonlitó elemzését végeztük el. Eredmények: Az 1986 beteg (nők: 59,9\%) átlagos életkora 58,29 (SD=16,62) év volt. Az informális ellátás (maximum 24 óra/nap) költsége átlagosan $7399(S D=25648)$ forint/beteg/hét volt, az igénybevevők alcsoportjában 24509 ( $S D=42281)$ forint/beteg/hét. A legsúlyosabb állapotúak (EQ-5D-3L index $\leq 0, N=162 ; 9,1 \%)$ közül 51 beteg (31,5\%) nem kapott informális ellátást és 15-en egyedül éltek. Következtetések: Magyarországon az informális ellátás költsége jelentös. Számos betegségben azonban nincs adat, pedig ezek alapvetöek lennének a megfelelö egészségpolitikai döntések meghozatalához és a fenntartható finanszírozás kialakításához.

Background: The costs of informal care are not available in Hungary. Objectives: To measure informal care costs in chronic diseases. Methods: Thirteen previous studies were analysed. Results: The average age of the 1986 patients $(59,9 \%$ female) was 58.29 (SD = 16.62) years. The average cost of informal care (24-hour limit) was 7399 (SD=25648) HUF/patient, in those who received informal care: 24509 (SD =42281) HUF/patient. Of the patients in the worst health states (EQ-5D-3L index $\leq 0, N=162 ; 9.1 \%) 51$ (31.5\%) didn't receive informal care and 15 lived alone. Conclusions: The informal care costs are considerable, however data needed to support health policy decisions and achieve sustainable funding is often missing.

\section{BEVEZETÉS}

Az informális ellátás a betegek, gondozásra szorulók egészségügyi és szociális ellátás formális, államilag finanszírozott keretein kívüli, a társadalombiztosítás által nem térített gondozását

\footnotetext{
${ }^{1}$ a tanulmány megírásának idején PhD hallgató, Budapesti Corvinus Egyetem, Gazdálkodástani Doktori Iskola
}

DOI: 10.14267/RETP2020.03.12 
jelenti. Ennek során a betegek a családtagoktól, az egy háztartásban élőktől, barátoktól, szomszédoktól, segítő szervezetektől segítséget kapnak a napi teendőik ellátásához (öltözködés, tisztálkodás, étkezés, házimunka), a segítők bevásárolnak, kiváltják a recepteket, illetve más ügyeket intéznek, elkísérik a beteget az egészségügyi intézményekbe. Az informális ellátás sok segítő (informális ellátó) sok idejét veszi igénybe, sokan ráadásul emiatt kiesnek vagy mulasztanak a munkából. Mindezek miatt az informális ellátás napjainkban egyre fontosabbá váló terület [Beretzky et al., 2017; Gulacsi et al., 2012; Zrubka, 2017]. Az informális ellátásra fordított időt és az azzal kapcsolatosan felmerülő terheket a betegséggel összefüggő költségnek tekinthetjük, amennyiben feltételezzük, hogy ennek hiányában ezt a gondozási tevékenységet formális egészségügyi, szociális ellátással lenne szükséges helyettesíteni. Krónikus, hosszan, akár több évtizeden át is tartó megbetegedésekben még fontosabb az informális ellátás. Fontos ennek a szerepe az idősödő társadalmak esetén, hiszen a várható élettartam jelentősen növekedett és növekszik, az emberek egyre hosszabban élnek, hosszabb időt töltenek kisebb vagy nagyobb mértékben csökkent önellátási képességgel, így átmenetileg vagy tartósan mások segítségére szorulnak [Verbakel et al., 2017]. 2015-ben az EU28-tagállamok lakossága körében a 65 év felettiek aránya 18,9\% volt, míg hazánkban 17,9\% [Eurostat, 2017]. A „baby-boomer” korosztályok öregedése is jelentősen növeli a gondozási szükségleteket.

Az informális ellátás igénye azonban nem csak az idős korosztályra korlátozódik. Egyre nagyobb számú gyerek és fiatal felnőtt él súlyos krónikus megbetegedéssel és igényel informális ellátást. Ilyenek például az úgynevezett ritka betegségek (különösen azok veleszületett formái), amelyek esetén a betegek száma egy-egy megbetegedésben nem magas, de a több mint ezer ritka betegségeben több százezer beteg érintett [Cavazza et al., 2016a; Cavazza et al., 2016b; Chevreul et al., 2016a; Chevreul et al., 2016b; Iskrov et al., 2016; Kuhlmann et al., 2016; Pentek et al., 2016a; Péntek et al., 2016b]. Az egyre hatékonyabb orvosi technológiák alkalmazásának eredményeképpen a fejlett országokban, így hazánkban is, jelentősen emelkedik a krónikus megbetegedésekkel élők várható élettartama és száma. Jól megfigyelhető ez a tendencia az európai országokban is, ahol jelentősen emelkedett az aktivitást korlátozó krónikus betegségek előfordulási gyakorisága. Ezek közül is kiemelhetők a demencia, a csontritkulás, a szív- és érrendszeri megbetegedések, valamint a daganatos betegségek.

Napjainkban, a krónikus betegségben szenvedők esetén az informális ellátás költsége igen magas, az esetek jelentős részében meghaladja a direkt egészségügyi költségeket [Eurostat, 2017; Hoefman et al., 2013]. Ezek a költségek az Amerikai Egyesült Âllamokban már évtizedek óta meghaladják a biztosítás és állam által finanszírozott egészségügyi szektor költségeit [Arno et al., 1999]. Az informális ellátás bizonyos mértékben helyettesítheti a biztosítás, illetve állam által finanszírozott egészségügyi/szociális ellátást, ezáltal csökkentheti ezeket az egészségügyi kiadásokat [Boncz et al., 2006; Bremer et al., 2015]. Lényeges szempont azonban az is, hogy az informális gondozók egészsége esetenként romlik és a munkaképessége csökken [Colombo et al., 2011]. A jelenleg megfigyelhető demográfiai trendek további fennállása mellett előrejelezhető, hogy az informális ellátás iránti szükséglet a továbbiakban is jelentősen nőni fog [KSH, 2013; Vlachantoni et al., 2013].

Kutatásunk célja az informális ellátás költségeinek áttekintése különböző krónikus betegségekben Magyarországon. Elemzésünk korábbi vizsgálatokra épít, amelyekben betegszintü adatok állnak rendelkezésünkre.

\section{Módszer}


A részletes módszertant más publikációnkban közöltük [Beretzky et al., 2017]. A Budapesti Corvinus Egyetem Egészségügyi Közgazdasági Tanszékén az elmúlt években végzett kérdöíves kutatások közül azokat tekintettük át, amelyek az informális ellátás felmérésére is kiterjedtek, és használták az egészségi állapot mérésére alkalmas EQ-5D-3L kérdőívet (lásd lentebb). A kutatások során a tanszék által összeállított és a betegek által kitöltött kérdéssorok kerültek alkalmazásra, amelyek segítségével az informális ellátást a kitöltést megelőző hétre vonatkozóan mérték fel. Összesen 13 kutatás eredményének a másodlagos elemzését végeztük el a következő betegségekben: artritisz pszoriatika (AP, pikkelysömörös ízületi gyulladás) [Brodszky et al., 2009], időskori makuladegeneráció (age-related macular degeneration - AMD) [Brodszky et al., 2014], demencia [Ersek et al., 2010], endometriózis [Simoens et al., 2012], epilepszia [Pentek et al., 2013], jóindulatú prosztatamegnagyobbodás (benign prostatic hyperplasia - BPH) [Rencz et al., 2015], oszteoporózis (csontritkulás) [Pentek et al., 2016], Parkinson kór [Tamas et al., 2014], pszoriázis (pikkelysömör) [Balogh et al., 2014; Rencz et al., 2014], reumatoid artritisz (RA, sokízületi gyulladás) [Pentek et al., 2007], szisztémás szklerózis (SSc) [Minier et al., 2010] [Pentek et al., 2012], skizofrénia [Pentek et al., 2012].

\section{1. ÉLETMINŐSÉG MÉRÉSE}

Az egészséggel összefüggő életminőség felmérésére az EQ-5D-3L validált magyar változatát használtuk. Az EQ-5D-3L kérdőív az egészség általános aspektusait méri fel és két részből áll [Péntek, 2013; Rencz, 2012]. Az EQ-5D-3L ún. deskriptív része az egészség öt dimenziójának (Mozgékonyság, Önellátás, Szokásos tevékenységek, Fájdalom/rossz közérzet, Szorongás/lehangoltság) vizsgálatát foglalja magában [EuroQolGroup, 1990]. Mind az öt dimenzióban háromféle választási lehetőség közül kell a válaszadónak megjelölnie az adott napi egyészségi állapotát legjobban jellemző választ (1-nincs probléma, 2-mérsékelt probléma, 3-képtelen rá/rendkívül erős probléma). Az öt dimenzióban kapott számértékek kombinációja jellemzi a válaszadó egészségi állapotát. Az EQ-5D-3L által leírt egészségi állapotokhoz lakossági preferencia-érték, úgynevezett hasznosság társítható (EQ-5D-3L index). Az egészség-gazdaságtani elemzésekben legygyakrabban ebből számolják az életminőséggel korrigált életéveket (Quality Adjusted Life Year, QALY) az egészségnyereség kifejezésére [Szende et al., 2003].

Az értékeléshez kutatásunkban az Egyesült Királyság hasznosság-értékkészletét használtuk fel [Devlin et al., 2017], mivel magyar tarifa jelenleg nem áll rendelkezésre, és lakossági felmérésekben is ezt alkalmazták [Baji et al., 2015]. Az EQ-5D-3L index értéktartománya -0,549 - 1, a magasabb érték jobb állapotot jelent. A kérdőív második része egy 0-100 fokozatú vizuális analóg skála, az EQ VAS, melyen a betegnek meg kell jelölnie az aznapi állapotát. A skálán a 0 az elképzelhető legrosszabb, a 100 pedig az elképzelhető legjobb állapotot jelenti.

Elemzésünkben külön figyelmet szerettünk volna fordítani a legrosszabb egészségi állapotban élők helyzetének a vizsgálatára. Ehhez az EQ-5D-3L segítségével számolt hasznosságokat (EQ-5D-3L index) vettük figyelembe, mégpedig úgy, hogy a legfeljebb 0-val egyenlő hasznossággal rendelkezőket tekintettük a legrosszabb egészségi állapotban élöknek. 


\subsection{INFORMÁLIS ELLÁTÁS}

Az informális ellátás túlbecslésének elkerülése érdekében a más személytől kapott segítség idejét alapesetben betegenként 24 óra/nap (azaz heti 168 óra) időre maximáltuk. Másodlagos elemzésünkben egy konzervatívabb megközelítést alkalmaztunk és napi 8 (azaz heti 56 órában) maximáltuk az informális ellátás óraszámát betegenként. Az informális ellátás költségének meghatározásához a heti szinten igénybe vett informális ellátás óraszámát használtuk alapul. Az óraszámokat az átlagos nettó órabérrel szoroztuk fel, amely 973 forint volt 2017-ben [KSH, 2017].

\section{EREDMÉNYEK}

Az elemzésünkbe bevont 13 kutatásba összesen 1896 beteg került beválogatása, átlagos életkoruk 58,29 (SD=16,62) év volt, közülük 59,9\% volt nő, az ő átlagos életkoruk 57,45 (SD 16,98) év volt, a férfiaké pedig 59,51 ( $\mathrm{SD}=16,01)$ év. A vizsgálatok a jelentős, nagy prevalenciájú betegségekre és a ritkábban előforduló megbetegedésekre egyaránt kiterjedtek, a három legnagyobb betegszámmal rendelkező betegség az oszteoporózis $(\mathrm{n}=282)$, az RA $(\mathrm{N}=255)$ és a BPH $(\mathrm{N}=246)$ volt. A betegek általános egészségi állapota az EQ-5D-3L index átlaga szerint 0,629 ( $\mathrm{SD}=0,331)$ és a

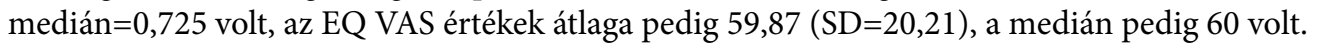

A betegek 27,4\%-a részesült informális ellátásban, arányuk 6,5\% (BPH) és 87,2\% (demencia) között mozgott a különböző betegségekben. A betegek több mint egyharmada vett igénybe informális ellátást demencia (87,2\%), RA (49,8\%), SSc (38,8\%), AP (37,7\%) és SM (36,8\%) betegcsoportok esetében.

\subsection{Az EQ-5D-3L EGYES DIMENZIÓIBAN PROBLÉMÁT JELZŐ BETEGEK INFORMÁLIS ELLÁTÁS IGÉNYBEVÉTELE}

Az Önellátás dimenzióban némi problémát jelentők informális ellátásának heti átlagos óraszáma napi 24 órás limitet alkalmazva $8,13(\mathrm{SD}=16,95)$ óra/hét, 8 órás limittel pedig 7,33 $(\mathrm{SD}=11,42)$ óra/hét volt. Az informális ellátásban nem részesülök 15,9\%-a ebben a dimenzióban némi probléma fennállását jelentette. Leginkább a Mozgékonyság, az Önellátás és a Szokásos tevékenységek dimenziókban figyelhető meg, hogy a súlyos probléma/képtelen válaszokat megjelölök esetében rendkívül magas az informális ellátás heti átlagos óraszáma (1. táblázat).

1. táblázatAz EQ-5D egyes dimenzióiban problémát jelentők informális ellátás igénybevétele

\begin{tabular}{|c|c|c|c|}
\hline \multirow{2}{*}{ Eq-5D dimenzió } & \multicolumn{2}{|c|}{$\begin{array}{l}\text { Informális ellátásban részesülő betegek } \\
\text { Informális ellátás heti óraszáma, átlag (SD) }\end{array}$} & \multirow{2}{*}{$\begin{array}{c}\text { Betegek aránya, akik nem } \\
\text { részesültek informális } \\
\text { ellátásban (\%) }\end{array}$} \\
\hline & $\begin{array}{l}\text { Heti } 56 \text { órában } \\
\text { maximálva }\end{array}$ & $\begin{array}{l}\text { Heti } 168 \text { órában } \\
\text { maximálva }\end{array}$ & \\
\hline \multicolumn{4}{|l|}{ Mozgékonyság } \\
\hline Nincs probléma & $1,36(6,32)$ & $1,74(10,42)$ & $54,30 \%$ \\
\hline Némi probléma & $5,10(10,78)$ & $6,55(20,35)$ & $45,40 \%$ \\
\hline Ágyhoz kötött & $14,62(16,81)$ & $23,23(44,94)$ & $0,30 \%$ \\
\hline
\end{tabular}




\begin{tabular}{|c|c|c|c|}
\hline \multicolumn{4}{|c|}{ Önellátás (tisztálkodás, öltözködés) } \\
\hline Nincs probléma & $1,73(6,91)$ & $2,38(13,36)$ & $83,40 \%$ \\
\hline Némi probléma & $7,33(11,42)$ & $8,13(16,95)$ & $15,90 \%$ \\
\hline Képtelen & $19,28(20,89)$ & $34,86(56,24)$ & $0,60 \%$ \\
\hline \multicolumn{4}{|c|}{ Szokásos tevékenységek } \\
\hline Nincs probléma & $1,13(5,90)$ & $1,60(11,27)$ & $62,60 \%$ \\
\hline Némi probléma & $5,37(10,65)$ & $6,50(18,53)$ & $35,20 \%$ \\
\hline Képtelen & $11,58(16,18)$ & $17,69(38,23)$ & $2,20 \%$ \\
\hline \multicolumn{4}{|c|}{ Fájdalom/rossz közérzet } \\
\hline Nincs & $1,85(7,69)$ & $2,2911,86)$ & $41,60 \%$ \\
\hline Mérsékelt & $3,73(9,43)$ & $4,74(17,21)$ & $51,20 \%$ \\
\hline Nagyon erős & $7,42(11,95)$ & $10,24(26,80)$ & $7,30 \%$ \\
\hline \multicolumn{4}{|c|}{ Szorongás/lehangoltság } \\
\hline Nincs & $1,79(6,73)$ & $2,18(10,98)$ & $54,40 \%$ \\
\hline Mérsékelten & $4,71(10,98)$ & $6,41(21,64)$ & $40,60 \%$ \\
\hline Nagyon & $6,97(10,81)$ & $7,89(17,62)$ & $5,00 \%$ \\
\hline
\end{tabular}

Forrás: saját szerkesztésű táblázat

\subsection{A LEGROSSZABB EGÉSZSÉGI ÁLLAPOTBAN LEVŐ BETEGEK INFORMÁLIS ELLÁTÁSA}

A legrosszabb egészségi állapotban lévő betegek azonositásához megvizsgáltuk, hogy mely betegek rendelkeztek 0 vagy annál alacsonyabb EQ-5D-3L index értékkel. 162 (9,1\%) ilyen beteget azonosítottunk. Közülük 26,1\% RA-ban, 17,6\% PsA-ban, 13,9\% demenciában és 13,3\% oszteoporózisban szenvedett. Egyedül az endometriózisban nem volt egyetlen olyan beteg sem, akinek EQ-5D-3L értéke 0 vagy alacsonyabb volt. A legrosszabb egészségi állapotot tapasztalók átlagos életkora 62,1 év volt ( $\mathrm{SD}=14,6$ év) és $66 \%$-a volt nő. A 0 vagy annál rosszabb EQ-5D-3L index értékkel rendelkezők 31\%-a egyedül élt.

A legrosszabb egészségi állapottal rendelkezők közül 51 fö (31,5\%) nem kapott informális ellátást, és közülük 15-en egyedül éltek. Az informális ellátás átlagos heti óraszáma a 24 órás limitet használva $18,71(\mathrm{SD}=39,43)$, a 8 órás limitet alkalmazva pedig $11,65(\mathrm{SD}=16,79)$ óra volt. A legmagasabb átlagos heti informális segítség igénybevétel ez esetben demenciában és Parkinson kórban volt megfigyelhetö. A 0-nál magasabb EQ-5D-3L index értékkel rendelkezőkkel összehasonlítva látható, hogy a legrosszabb egészségi állapotban élők átlagos informális ellátás óraszáma minden diagnózisban magasabb (2. táblázat). 
2. táblázat $A$ legrosszabb egészségi állapotúak $(\mathrm{N}=165)$ informális ellátása betegségtípusonként*

\begin{tabular}{|c|c|c|c|c|}
\hline \multirow{3}{*}{ Betegség } & \multicolumn{4}{|c|}{ Informális ellátás heti óraszáma/ fó átlag (SD) } \\
\hline & \multicolumn{2}{|c|}{$\begin{array}{c}\text { Legrosszabb egészségi állapotú } \\
\text { betegek }^{\star *}\end{array}$} & \multicolumn{2}{|c|}{$\begin{array}{c}\text { 0-nál magasabb EQ-5D-3L index } \\
\text { értékkel rendelkező betegek }\end{array}$} \\
\hline & $\begin{array}{l}\text { Heti } 56 \text { órában } \\
\text { maximálva }\end{array}$ & $\begin{array}{l}\text { Heti } 168 \text { órában } \\
\text { maximálva }\end{array}$ & $\begin{array}{l}\text { Heti } 56 \text { órában } \\
\text { maximálva }\end{array}$ & $\begin{array}{l}\text { Heti } 168 \text { órában } \\
\text { maximálva }\end{array}$ \\
\hline $\begin{array}{l}\text { Artritisz pszoriatika } \\
\text { (PsA) }\end{array}$ & $10,72(9,98)$ & $10,72(9,98)$ & $4,52(10,53)$ & $6,03(20,88)$ \\
\hline $\begin{array}{l}\text { Pikkelysömör } \\
\text { (Pszoriázis) }\end{array}$ & $11,52(17,93)$ & $22,72(51,80)$ & $0,25(1,09)$ & $0,25(1,09)$ \\
\hline $\begin{array}{l}\text { Időskori makula } \\
\text { degeneráció (AMD) }\end{array}$ & $1,33(2,65)$ & $1,33(2,65)$ & $2,83(8,26)$ & $2,83(8,26)$ \\
\hline $\begin{array}{l}\text { Reumatoid artritisz } \\
\text { (RA) }\end{array}$ & $8,02(11,51)$ & $8,99(16,42)$ & $5,35(9,78)$ & $5,93(14,08)$ \\
\hline $\begin{array}{l}\text { Szisztémás szklerózis } \\
\text { (SSc) }\end{array}$ & $2,33(4,04)$ & $2,33(4,04)$ & $5,79(12,34)$ & $7,42(21,99)$ \\
\hline Demencia & $39,63(19,71)$ & $79,21(64,09)$ & $31,21(24,82)$ & $69,77(71,67)$ \\
\hline Oszteoporózis & $4,77(7,31)$ & $4,77(7,31)$ & $1,07(4,85)$ & $1,68(12,61)$ \\
\hline $\begin{array}{l}\text { Jóindulatú prosztata- } \\
\text { megnagyobbodás } \\
\text { (BPH) }\end{array}$ & $0^{\star * *}$ & $0^{\star * *}$ & $1,54(7,05)$ & $1,57(7,32)$ \\
\hline Epilepszia & $1,86(2,73)$ & $1,86(2,73)$ & $2,56(10,34)$ & $5,57(27,02)$ \\
\hline Parkinson kór & $6,33(18,63)$ & $18,78(55,96)$ & $8,87(15,58)$ & $12,07(29,58)$ \\
\hline Skizofrénia & $6,8(9,55)$ & $6,8(9,55)$ & $3,44(6,64)$ & $3,44(6,64)$ \\
\hline $\begin{array}{l}\text { Szklerózis multiplex } \\
\text { (SM) }\end{array}$ & $5^{\star * *}$ & $5^{\star \star *}$ & $13,91(16,63)$ & $19,39(36,15)$ \\
\hline
\end{tabular}

Forrás: saját szerkesztésű táblázat

* Endometriózisban nem volt egyetlen olyan beteg sem, akinek EQ-5D-3L értéke 0 vagy alacsonyabb volt

${ }^{* *}$ EQ-5D-3L index értékük kisebb vagy egyenlő 0

${ }^{* * *} \mathrm{~N}=1$ fö

\subsection{Az INFORMÁliS ELLÁtÁs KöltSÉGE}

Az informális ellátás heti költsége a teljes mintánkban a 24 órás limitet alkalmazva átlagosan 7399 ( $\mathrm{SD}=25648)$, napi 8 órás limitet használva pedig $4696(\mathrm{SD}=11828)$ forint/beteg volt. A több mint (egy változó szerint) történő összehasonlítására alkalmas Kruskal-Wallis teszt eredményei alapján a költségek szignifikánsan eltérőek az eltérő diagnózisokban mind elsődleges, mind másodlagos elemzésünk szerint ( $\mathrm{p}<0,001$ mindkét esetben). 
3. táblázat Az igénybe vett informális ellátás költsége (Ft/beteg/hét) betegségtípusonként

\begin{tabular}{|l|c|c|c|c|}
\hline \multicolumn{1}{|c|}{ Betegségek } & \multirow{2}{*}{$\begin{array}{c}\text { Betegszám } \\
(\mathbf{n})\end{array}$} & $\begin{array}{c}\text { Informális } \\
\text { ellátás igénybe } \\
\text { vevök aránya } \\
\text { (\%) }\end{array}$ & $\begin{array}{c}\text { Az informális ellátást igénybe vevök } \\
\text { informális ellátás költsége, átlag (SD) }\end{array}$ \\
\cline { 4 - 5 } & & $\begin{array}{c}\text { Heti 56 órában } \\
\text { maximálva }\end{array}$ & $\begin{array}{c}\text { Heti 168 órában } \\
\text { maximálva }\end{array}$ \\
\hline $\begin{array}{l}\text { Artritisz pszoriatika } \\
\text { (PsA) }\end{array}$ & 183 & $37,7 \%$ & $14130(12527)$ & $17288(27474)$ \\
\hline $\begin{array}{l}\text { Pikkelysömör } \\
\text { (Pszoriázis) }\end{array}$ & 200 & $9,5 \%$ & $8204(12756)$ & $13939(36718)$ \\
\hline $\begin{array}{l}\text { Idöskori makula } \\
\text { degeneráció (AMD) }\end{array}$ & 122 & $27,9 \%$ & $9752(12520)$ & $9752(12520)$ \\
\hline $\begin{array}{l}\text { Reumatoid artritisz } \\
\text { (RA) }\end{array}$ & 255 & $49,8 \%$ & $11168(11350)$ & $12401(17787)$ \\
\hline $\begin{array}{l}\text { Szisztémás szklerózis } \\
\text { (SSc) }\end{array}$ & 80 & $38,8 \%$ & $14203(15489)$ & $18157(30904)$ \\
\hline Demencia & 86 & $87,2 \%$ & $37218(20899)$ & $80530(66503)$ \\
\hline Endometriózis & 84 & $9,5 \%$ & $12223(11470)$ & $12223(11470)$ \\
\hline Oszteoporózis & 281 & $14,9 \%$ & $8816(11882)$ & $14132(34695)$ \\
\hline $\begin{array}{l}\text { Jóindulatú prosztata- } \\
\text { megnagyobbodás (BPH) }\end{array}$ & 246 & $6,5 \%$ & $22075(15920)$ & $22561(16995)$ \\
\hline Epilepszia & 100 & $13,5 \%$ & $18876(21152)$ & $39743(61801)$ \\
\hline Parkinson kór & 109 & $31,8 \%$ & $10376(16208)$ & $14642(33074)$ \\
\hline Skizofrénia & 78 & $30,8 \%$ & $11554(7181)$ & $11554(7181)$ \\
\hline $\begin{array}{l}\text { Szklerózis multiplex } \\
\text { (SM) }\end{array}$ & 24 & $36,8 \%$ & $14374(16120)$ & $19947(35678)$ \\
\hline
\end{tabular}

Forrás: saját szerkesztésű táblázat

Az informális ellátás átlagos költsége a női betegek esetében magasabb volt, mint a férfiaké a 24 és a 8 órás limit alkalmazása esetében is: $4004(\mathrm{SD}=11617)$ és $5144(\mathrm{SD}=11971)$ valamint 6827 $(\mathrm{SD}=26522)$ és $7680(\mathrm{SD}=25116)$ forint. Mann-Whitney U-teszt eredményei alapján az eltérés mindkét esetben szignifikáns ( $\mathrm{p}<0,001$ mindkét esetben).

Az informális ellátás költsége csak az informális ellátást igénybe vevőkre vonatkozóan átlagosan heti $24509(\mathrm{SD}=42281)$ forint/beteg volt a napi 24 órás limitet, és $15646(\mathrm{SD}=17100)$ forint a napi 8 órás limitet alkalmazva. A legmagasabb költség demenciában (napi 24 órás limitet alkalmazva $80530 \mathrm{Ft} /$ beteg/hét és napi 8 órás limittel 37218 Ft/beteg/hét), a legalacsonyabb költség időskori makula degenerációban (9752 Ft/beteg/hét) és endometriózisban (12223 Ft/beteg/hét) volt megfigyelhetö. A 8 órás limittel számolva a legalacsonyabb költség azonban a pikkelysömör esetében volt megfigyelhetö (8204 (SD=12756) Ft/beteg/hét) (3. táblázat). A nemek közötti különbség ez esetben nem mutat szignifikáns eltérést a Mann-Whitney U-teszt eredményei alapján ( $\mathrm{p}=0,346$ és $\mathrm{p}=0,383)$. 


\subsection{INFORMÁLIS ELLÁTÁS KÖLTSÉGÉT MEGHATÁROZÓ TÉNYEZŐK}

A változók közötti kapcsolat felderítésére Spearmann-féle rangkorrelációt számoltunk. Közepesnél gyengébb, negatív irányú kapcsolat volt megfigyelhető a heti informális ellátás költsége és a betegek életminőségét kifejező EQ-5D-3L index $(r=-0,415, p<0,001)$, valamint EQ VAS érték $(r=-0,326, p<0,001)$ között, azaz a rosszabb állapotban levő betegek több informális ellátást kaptak. Rendkívül gyenge, de szignifikáns kapcsolatot találtunk az informális ellátás költsége és az életkor között $(\mathrm{r}=0,094, \mathrm{p}<0,001)$, tehát az idősebb betegek több informális ellátásban részesültek, mint a fiatalabbak.

\subsection{AZ INFORMÁLIS ELLÁTÁS ÉVES KÖLTSÉGEI}

4. táblázat Az informális ellátás becsült költsége/beteg/év (HUF) Magyarországon

\begin{tabular}{|c|c|c|c|}
\hline Betegségek & $\begin{array}{c}\text { Prevalencia } \\
\text { Magyarországon }\end{array}$ & $\begin{array}{l}\text { Becsült átlagos } \\
\text { betegszám } \\
\text { Magyarországon }\end{array}$ & $\begin{array}{c}\text { Az informális ellátás } \\
\text { becsült költsége/ } \\
\text { beteg/év (HUF) }\end{array}$ \\
\hline $\begin{array}{l}\text { Artritisz pszoriatika } \\
\text { (PsA) }\end{array}$ & $\begin{array}{l}\text { 0,1-0,3\% [Brodszky et al., } \\
\text { 2009, Brodszky et al., 2010] }\end{array}$ & 20000 & 858805 \\
\hline $\begin{array}{l}\text { Pikkelysömör } \\
\text { (Pszoriázis) }\end{array}$ & $\begin{array}{l}\text { 0,73-2,9\% [Balogh et al., } \\
\text { 2014, Herszényi et al., OEP, } \\
\text { 2009, Rencz et al., 2015] }\end{array}$ & 181500 & 125635 \\
\hline $\begin{array}{l}\text { Időskori makula } \\
\text { degeneráció (AMD) }\end{array}$ & $\begin{array}{l}\text { 0,1\%-9,8\% [Colijn et al., } \\
\text { 2017, Pentek et al., 2017] }\end{array}$ & 115390 & 426510 \\
\hline $\begin{array}{l}\text { Reumatoid artritisz } \\
\text { (RA) }\end{array}$ & $\begin{array}{l}\text { 0,5\% [Dorner et al., } \\
\text { 2016, Gulacsi et al., 2016, } \\
\text { Herszényi et al., Kiss et al., } \\
\text { 2005, Lepp-Gazdag et al., } \\
\text { 2002, Pentek et al., 2007] }\end{array}$ & 50000 & 896645 \\
\hline $\begin{array}{l}\text { Szisztémás szklerózis } \\
\text { (SSc) }\end{array}$ & $\begin{array}{c}0,7-48,9 / 100000[\text { Minier et } \\
\text { al., 2010] }\end{array}$ & 24800 & 887169 \\
\hline Demencia & $\begin{array}{c}1316 / 100000 \text { [Ersek et al., } \\
2010 \text { ] }\end{array}$ & 131995 & 5233482 \\
\hline Endometriózis & 2-10\% [Simoens et al., 2012] & 600000 & 187657 \\
\hline Oszteoporózis & $\begin{array}{l}\text { 2,5-21,2\%^ [Hernlund et al., } \\
\text { 2013, Raspe et al., 1998] }\end{array}$ & $\begin{array}{c}600000 \text { nő és } \\
300000 \text { férfi }^{\star} \\
\text { [OEP, 2013, Pentek } \\
\text { et al., 2016] }\end{array}$ & 207363 \\
\hline $\begin{array}{l}\text { Jóindulatú prosztata- } \\
\text { megnagyobbodás } \\
(\mathrm{BPH})\end{array}$ & $\begin{array}{l}\text { férfiak 8-90\%-a }{ }^{\star * *}[\text { Rencz, } \\
2012]\end{array}$ & $\begin{array}{l}415000 \text { [Rencz et } \\
\text { al., 2015] }\end{array}$ & 231446 \\
\hline Epilepszia & $\begin{array}{c}\text { 0,3-0,6\% [EMMI, 2017, } \\
\text { Pentek et al., 2013] }\end{array}$ & 45000 & 393687 \\
\hline
\end{tabular}




\begin{tabular}{|l|c|c|c|}
\hline Parkinson kór & $\begin{array}{c}100-200 / 100000 \text { [OEP, 2013, } \\
\text { Olesen et al., 2012, Tamas et } \\
\text { al., 2014] }\end{array}$ & $\begin{array}{c}20000 \text { [Tamas et } \\
\text { al., 2014] }\end{array}$ & 1366661 \\
\hline Skizofrénia & $1 \%[$ OEP, 2010] & 100000 & 573097 \\
\hline $\begin{array}{l}\text { Szklerózis multiplex } \\
\text { (SM) }\end{array}$ & $25-224 / 100000[\mathrm{OEP}, 2010]$ & 7000 & 2123978 \\
\hline
\end{tabular}

Forrás: saját szerkesztésü táblázat

${ }^{\star}$ Nem és korcsoport alapján eltérő prevalencia értékek

${ }^{* *}$ A mintánkban oszteoporózisban szenvedő betegek közül 60\%-nak volt valamilyen felnőtkori csonttörése.

***30 éves kor alatt nem jelentkezik, 31-40 év között 8\%, 41-50 év között 20\%, 51-60 év között már 50\%, 61-70 év között 70\%, 71-80 év között 80\%, 80 év fölötti korcsoportban pedig $90 \%$ a BPH elöfordulása a férfi lakosság körében.

A 4. táblázatban az egyes megbetegedésekben az egy beteg egy évre eső informális költségét tüntettük fel a konzervatívabb becslést biztosító napi 8 órás informális ellátás idő limittel számolva. Az egy betegre számolt átlagos éves költségek 125635 Ft (pszoriázis) és 5233482 Ft (demencia) között mozogtak (4. táblázat).

\section{MegbeSZÉLÉS, KONKLÚZió}

Az informális ellátás költsége a nemzetközi adatokhoz hasonlóan hazánkban is igen magas, ezt vizsgálatunk eredményei egyértelmüen igazolják. A jelen tanulmányban felhasznált kutatások során olyan betegek kerültek bevonásra, akik betegségük miatt járóbetegellátást illetve kórházi kezelést vettek igénybe, és a betegminták ezeknek a betegeknek a csoportját reprezentálják.

$\mathrm{Az}$ informális ellátás pontos összegének kalkulálásához azonban tudnunk kellene azt, hogy az általunk vizsgált megbetegedések esetén vizsgálati eredményeink milyen mértékben általánosíthatók a megbetegedésben szenvedők teljes populációjára. Ezt nem ismerjük, ezeket az információkat a rutinszerüen gyüjtött adatok adatbázisai sem tartalmazzák (NEAK, korábban OEP és más népegészségügyi adatbázisok), erre pedig szükségünk lenne az összegek megbízható kalkulálásához [KSH, 2009; OECD, 2017]. Lakossági adatok vannak különböző felmérésekből arra vonatkozóan, hányan nyújtanak, illetve kapnak informális ellátást az idősebb korosztályban Magyarországon. Ezek azonban nem tartalmaznak konkrét diagnózisokhoz, illetve egészségi állapotokhoz köthető adatokat, így nem alkalmasak a különböző betegségek okozta betegségteher becslésére az egészség-gazdaságtani elemzések során.

$\mathrm{Az}$ informális ellátás költségének mérése nemzetközi tanulmányokban is megjelenik. Krol és munkatársai szisztematikus irodalom-áttekintésében szintén megjelent a reumatoid artritisz is. A szerzők a reumatoid artritisz betegek esetében felmerülő informális ellátás esetében széles tartományt lefedő költségekre vonatkozó eredményeket találtak (569 - 181,620 euró) [Krol et al., 2015].

Ezeknek az összegeknek az ismerete szükséges ahhoz, hogy az egészségpolitika fel tudja mérni a megbetegedések valós társadalmi költségét és fontosságát. Az informális ellátás költségeinek ismerete nélkül nem lehetséges megalapozott egészségpolitikai és finanszírozási döntéseket hozni. A lakosság, a betegek informális ellátás iránti igényét a felmérések egyértelmüen mutatják. A várható élettartam növekedése és az egyre nagyobb számú krónikus beteg ellátása 
jól előrejelezhetően növeli az informális ellátás iránti igényt. Az azonos háztartásban élők száma azonban már napjainkban sem magas és várhatóan csökkenni fog, emiatt várhatóan csökkenni fog az informális ellátók száma. Ugyanezt eredményezi az is, hogy ha hazánkban növekszik az aktív munkavállalók száma. Ezeknek a változásoknak az együttes hatása azt eredményezi, hogy az informális ellátás hiányában az állami vagy magán, azaz a formális egészségügynek kell biztosítania ezt az ellátást, amely jelentős kapacitás-, munkaerö- és költségtöbblet-igényt vetít előre. Meg kell említeni, hogy az egészségügyben és a szociális szférában jelenleg is igen jelentős a szakemberhiány, további, nagyobb számú szakember bevonása nem tünik lehetségesnek.

A továbbiakban célszerủ lenne pontosan megismerni az informális ellátás iránti igényt hazánkban annak érdekében, hogy az ellátás- és a finanszírozási igény ismert és tervezhető legyen akár az állam, akár a biztosítók számára. Továbbá célszerủ lenne pontosan megismerni nemcsak az informális ellátás iránti igényeket, hanem a nem megvalósuló igényeket is, és ezzel azonosítani a megfelelő ellátáshoz nem jutó, legveszélyeztetettebb betegeket magába foglaló csoportokat.

Az elemzés korlátai között meg kell említenünk, hogy az országos becslés annak feltételezésével készült, hogy a kutatásba bevont betegek jól reprezentálják a hazánkban található összes, a vizsgált betegségben szenvedő beteget. A vizsgálatok során nem vettük figyelembe, hogy egy betegnek többféle krónikus megbetegedése is lehet, emiatt a költséget felülbecsülhettük. A torzítás mértéke további kutatások nélkül megbecsülhetetlen. További lehetséges torzító tényező az is, hogy csak a konkrét igénybe vett informális ellátást mértük fel, azoknak a betegeknek az esetén, akik informális ellátást igényeltek volna, de erre valamilyen ok miatt nem volt mód, nem tudunk informális költséget kimutatni. Emiatt a tényleges költségeket alulbecsülhettük. További kutatások nélkül erre sem tudunk becslést tenni. További limitációként fontos megemlíteni, hogy a különböző években készült felmérésekben megjelenő óraszámokat 2017-es költségekkel számolva vettük figyelembe. Az eltelt időszakban azonban számos betegség kezelése jelentősen változhatott, az új eredményes terápiák bevezetése módosíthatta az informális ellátás óraszámát egyes betegség alcsoportokban (például: a reumatoid artritiszben szenvedő, immár biológiai gyógyszerekkel kezelt betegek).

Mindezek mellett is úgy véljük, hogy a becsült költségek nagyságrendileg megfelelök, és hazánkban is jelentős az informális ellátás költsége, amelynek ismerete szükséges a valós társadalmi teher megismeréséhez, a megfelelő egészségpolitikai döntések meghozatalához és a fenntartható finanszírozás kialakításához.

\section{FELHASZNÁlt IRODALOM}

BeretzkyZ.PéntekM.(2017):„Informális ellátásés meghatározó tényezőikrónikusbetegségekben: magyarországi kutatások összehasonlító elemzése." Orv Hetil. 158(52): 2068-2078.

Gulacsi L., Boncz I., Baji P. Pentek M. (2012): „Költségszámítás” in: Gulacsi. (szerk): Egészséggazdaságtan és techológiaelemzés. Medicina Könyvkiadó Nyrt. Budapest

Zrubka Z. (2017): „, Az informális ellátás mérése és egészség-gazdaságtani értékelése „Orv Hetil. 158(35): 1363-1372.

Verbakel E., Tamlagsronning S., Winstone L., Fjaer E. L. Eikemo T. A. (2017): "Informal care in Europe: findings from the European Social Survey (2014) special module on the social determinants of health" Eur J Public Health. 27(suppl_1): 90-95.

Eurostat (2017): Population structure and ageing, 2005 and 2015. http://ec.europa.eu/ eurostat/statistics-ex-plained/index.php/File:Population_age_structure_by_major_age_ 
groups_2005_and_2015_(\%25_of_the_total_population)_YB16.png. Lekérdezve: 2017. 12. 11.

Cavazza M., Kodra Y., Armeni P., De Santis M., Lopez-Bastida J., Linertova R., Oliva-Moreno J., Serrano-Aguilar P., Posada-de-la-Paz M., Taruscio D., Schieppati A., Iskrov G., Gulacsi L., von der Schulenburg J. M., Kanavos P., Chevreul K., Persson U., Fattore G. Network B.-R. R. (2016): "Social/economic costs and quality of life in patients with haemophilia in Europe" Eur J Health Econ. 17 (Suppl 1): 53-65.

Cavazza M., Kodra Y., Armeni P., De Santis M., Lopez-Bastida J., Linertova R., Oliva-Moreno J., Serrano-Aguilar P., Posada-de-la-Paz M., Taruscio D., Schieppati A., Iskrov G., Pentek M., von der Schulenburg J. M., Kanavos P., Chevreul K., Persson U., Fattore G. Network B.-R. R. (2016): "Social/economic costs and health-related quality of life in patients with Duchenne muscular dystrophy in Europe" Eur J Health Econ. 17 (Suppl 1): 19-29.

Chevreul K., Gandre C., Brigham K. B., Lopez-Bastida J., Linertova R., Oliva-Moreno J., Serrano-Aguilar P., Posada-de-la-Paz M., Taruscio D., Schieppati A., Iskrov G., Gulacsi L., von der Schulenburg J. M., Kanavos P., Persson U., Fattore G. Network B.-R. R. (2016): "Social/economic costs and health-related quality of life in patients with fragile $\mathrm{X}$ syndrome in Europe" Eur J Health Econ. 17 (Suppl 1): 43-52.

Chevreul K., Michel M., Brigham K. B., Lopez-Bastida J., Linertova R., Oliva-Moreno J., SerranoAguilar P., Posada-de-la-Paz M., Taruscio D., Schieppati A., Iskrov G., Pentek M., von der Schulenburg J. M., Kanavos P., Persson U., Fattore G. Network B.-R. R. (2016): "Social/ economic costs and health-related quality of life in patients with cystic fibrosis in Europe" Eur J Health Econ. 17 (Suppl 1): 7-18.

Iskrov G., Astigarraga I., Stefanov R., Lopez-Bastida J., Linertova R., Oliva-Moreno J., SerranoAguilar P., Posada-de-la-Paz M., Schieppati A., Taruscio D., Pentek M., von der Schulenburg J. M., Kanavos P., Chevreul K., Persson U., Fattore G. Network B.-R. R. (2016): "Social/ economic costs and health-related quality of life in patients with histiocytosis in Europe" Eur J Health Econ. 17 (Suppl 1): 67-78.

Kuhlmann A., Schmidt T., Treskova M., Lopez-Bastida J., Linertova R., Oliva-Moreno J., SerranoAguilar P., Posada-de-la-Paz M., Kanavos P., Taruscio D., Schieppati A., Iskrov G., Pentek M., Delgado C., von der Schulenburg J. M., Persson U., Chevreul K., Fattore G. Network B.-R. R. (2016): "Social/economic costs and health-related quality of life in patients with juvenile idiopathic arthritis in Europe" Eur J Health Econ. 17 (Suppl 1): 79-87.

Pentek M., Gulacsi L., Brodszky V., Baji P., Boncz I., Pogany G., Lopez-Bastida J., Linertova R., Oliva-Moreno J., Serrano-Aguilar P., Posada-de-la-Paz M., Taruscio D., Iskrov G., Schieppati A., von der Schulenburg J. M., Kanavos P., Chevreul K., Persson U., Fattore G. Network B.-R. R. (2016): "Social/economic costs and health-related quality of life of mucopolysaccharidosis patients and their caregivers in Europe” Eur J Health Econ. 17 (Suppl 1): 89-98.

Péntek M., Herczegfalvi Á., Molnár M. J., Szőnyi L. P., Kosztolányi G., Pfliegler G., Melegh B., Boncz I., Brodszky V., Baji P., Szegedi M., Pogány G. Gulácsi L. (2016): "Disease Burden of Duchenne Muscular Dystrophy Patients and Their Caregivers" Ideggyógyászati Szemle. 69(5-6):

Hoefman R. J., van Exel J. Brouwer W. (2013): "How to include informal care in economic evaluations" Pharmacoeconomics. 31(12): 1105-1119.

Arno P. S., Levine C. Memmott M. M. (1999): “The economic value of informal caregiving" Health Aff (Millwood). 18(2): 182-188. 
Boncz I. Sebestyén A. (2006): "Financial deficits in the health services of the UK and Hungary" Lancet. 368(9539): 917-918.

Bremer P., Cabrera E., Leino-Kilpi H., Lethin C., Saks K., Sutcliffe C., Soto M., Zwakhalen S. M. Wubker A. (2015): "Informal dementia care: Consequences for caregivers' health and health care use in 8 European countries" Health Policy. 119(11): 1459-1471.

Colombo F., Llena-Nozal A., Mercier J. Tjadens F. (2011): Help wanted? Providing and paying for long-term care. http://dx.doi.org/10.1787/9789264097759-en. Lekérdezve: 2017. 04. 22.

KSH (2013): Nyugdijak és egyéb ellátások, 2013. http://www.ksh.hu/docs/hun/xftp/ idoszaki/ regiok/orsz/nyugdij/nyugdij13.pdf Lekérdezve: 2017. 04. 22.

Vlachantoni A., Evandrou M., Falkingham J. Robards J. (2013): "Informal care, health and mortality" Maturitas. 74(2): 114-118.

Brodszky V., Balint P., Geher P., Hodinka L., Horvath G., Koo E., Pentek M., Polgar A., Sesztak M., Szanto S., Ujfalussy I. Gulacsi L. (2009): "Disease burden of psoriatic arthritis compared to rheumatoid arthritis, Hungarian experiment" Rheumatol Int. 30(2): 199-205.

Brodszky N., Péntek M., Bíro Z., Kölkedi Z., Dunai Á., Németh J., Gulácsi L. Resch M. (2014): "Időskori macula degenerációval élő betegek klinikai jellemzői és betegségterhei." Szemészet. 151(Suppl 1): 59-60.

Ersek K., Kovacs T., Wimo A., Karpati K., Brodszky V., Pentek M., Jonsson L., Gustavsson A., McDaid D., Kenigsberg P. A., Valtonen H. Gulacsi L. (2010): "Costs of dementia in Hungary" J Nutr Health Aging. 14(8): 633-639.

Simoens S., Dunselman G., Dirksen C., Hummelshoj L., Bokor A., Brandes I., Brodszky V., Canis M., Colombo G. L., DeLeire T., Falcone T., Graham B., Halis G., Horne A., Kanj O., Kjer J. J., Kristensen J., Lebovic D., Mueller M., Vigano P., Wullschleger M. D’Hooghe T. (2012): “The burden of endometriosis: costs and quality of life of women with endometriosis and treated in referral centres" Hum Reprod. 27(5): 1292-1299.

Pentek M., Bereczki D., Gulacsi L., Mikudina B., Aranyi Z., Juhos V., Baji P. Brodszky V. (2013): "Epilepsziával elő felnőttek felmérése Magyarországon: eletminőség és költségek." Ideggyogy Sz. 66(7-8): 251-261.

Rencz F., Kovacs A., Brodszky V., Gulacsi L., Nemeth Z., Nagy G. J., Nagy J., Buzogany I., Boszormenyi-Nagy G., Majoros A. Nyirady P. (2015): "Cost of illness of medically treated benign prostatic hyperplasia in Hungary" Int Urol Nephrol. 47(8): 1241-1249.

Pentek M., Gulacsi L., Toth E., Baji P., Brodszky V. Horvath C. (2016): "A szakellátásban megjelenő osteoporosisos nők 10 éves csonttöréskockázata a FRAX alapján” Orv Hetil. 157(4): 146-153.

Tamas G., Gulacsi L., Bereczki D., Baji P., Takats A., Brodszky V. Pentek M. (2014): "Quality of life and costs in Parkinson's disease: a cross sectional study in Hungary" PLoS One. 9(9): e107704.

Balogh O., Brodszky V., Gulacsi L., Heredi E., Herszenyi K., Jokai H., Karpati S., Baji P., Remenyik E., Szegedi A. Hollo P. (2014): "Cost-of-illness in patients with moderate to severe psoriasis: a cross-sectional survey in Hungarian dermatological centres" Eur J Health Econ. 15 (Suppl 1): S101-109.

Rencz F., Brodszky V., Pentek M., Balogh O., Remenyik E., Szegedi A., Hollo P., Karpati S., Jokai H., Herszenyi K., Heredi E., Szanto S. Gulacsi L. (2014): "Arthritis psoriaticával társuló középsúlyos és súlyos psoriasis betegségterhe Magyarországon" Orv Hetil. 155(48): 1913-1921. 
Pentek M., Kobelt G., Czirjak L., Szekanecz Z., Poor G., Rojkovich B., Polgar A., Genti G., Kiss C. G., Brodszky V., Majer I. Gulacsi L. (2007): "Costs of rheumatoid arthritis in Hungary" J Rheumatol. 34(6): 1437.

Minier T., Pentek M., Brodszky V., Ecseki A., Karpati K., Polgar A., Czirjak L. Gulacsi L. (2010): "Cost-of-illness of patients with systemic sclerosis in a tertiary care centre" Rheumatology (Oxford). 49(10): 1920-1928.

Pentek M., Gulacsi L., Rozsa C., Simo M., Iljicsov A., Komoly S. Brodszky V. (2012): "Health status and costs of ambulatory patients with multiple sclerosis in Hungary" Ideggyogy Sz. 65(9-10): 316-324.

Pentek M., Harangozo J., Egerhazi A., Kelemen O., Gulacsi L., Baji P., Mattyassy A., Erdelyi R., LehoczkyS., Orlewska E., Vartokne Hever N., Ferencz A. Brodszky V. (2012): “A szkizofréniával elő betegek egeszséggel összefüggő életminősége es betegség-terhe Magyarorszégon.” Psychiatr Hung. 27(1): 4-17.

Péntek M. (2013): Az életminőség mérése és közgazdaságtani jelentősége. Budapesti Corvinus Egyetem, Egészségügyi Közgazdaságtan Tanszék, Budapest

Rencz F. (2012): "A jóindulatú prosztata-megnagyobbodás egészség-gazdaságtani elemzése" Köz-Gazdaság. 7(3): 135-151.

EuroQolGroup (1990): "EuroQol--a new facility for the measurement of health-related quality of life." Health Policy. 16(3): 199-208.

Szende A. Németh R. (2003): "Health related quality of life of the Hungarian population [A magyar lakosság egészségi állapothoz kapcsolódó éleminősége]” Orv Hetil. 144(34): 16671674. [Hungarian].

Devlin N. J. Brooks R. (2017): “EQ-5D and the EuroQol Group: Past, Present and Future” Appl Health Econ Health Policy. 15(2): 127-137.

Baji P., Brodszky V., Rencz F., Boncz I., Gulacsi L. Pentek M. (2015): “[Health status of the Hungarian population between 2000-2010]" Orv Hetil. 156(50): 2035-2044.

KSH (2017): Gyorsjelntés. https://www.ksh.hu/docs/hun/xftp/gyor/ker/ker1712.html. Lekérdezve: 03/04/2018.

Brodszky V., Pentek M., Balint P. V., Geher P., Hajdu O., Hodinka L., Horvath G., Koo E., Polgar A., Sesztak M., Szanto S., Ujfalussy I. Gulacsi L. (2010): “Comparison of the Psoriatic Arthritis Quality of Life (PsAQoL) questionnaire, the functional status (HAQ) and utility (EQ-5D) measures in psoriatic arthritis: results from a cross-sectional survey" Scand J Rheumatol. 39(4): 303-309.

Herszényi K., Pap D., Polgár K., Jókai H., Wikonkál N., Inotai D., Tordai A., Rencz F., Brodszky V., Gulácsi L., Kárpáti S. Holló P. "Infekciók potenciális szerepe anti-TNF-a kezelés hatásvesztésének hátterében psoriasisban"

OEP (2009): A plakkos psoriasis diagnosztikája és kezelése "Finanszírozási protokoll - háttéranyag" http://site.oep.hu/prot/A_plakkos_psoriasis_finanszirozasi_protokoll_hatteranyaga.pdf. Lekérdezve: 2018. 03. 13.

Rencz F., Kemeny L., Gajdacsi J. Z., Owczarek W., Arenberger P., Tiplica G. S., Stanimirovic A., Niewada M., Petrova G., Marinov L. T., Kazandhieva J., Pentek M., Brodszky V. Gulacsi L. (2015): "Use of biologics for psoriasis in Central and Eastern European countries" J Eur Acad Dermatol Venereol. 29(11): 2222-2230.

Colijn J. M., Buitendijk G. H. S., Prokofyeva E., Alves D., Cachulo M. L., Khawaja A. P., CougnardGregoire A., Merle B. M. J., Korb C., Erke M. G., Bron A., Anastasopoulos E., Meester-Smoor 
M. A., Segato T., Piermarocchi S., de Jong P., Vingerling J. R., Topouzis F., Creuzot-Garcher C., Bertelsen G., Pfeiffer N., Fletcher A. E., Foster P. J., Silva R., Korobelnik J. F., Delcourt C. Klaver C. C. W. (2017): "Prevalence of Age-Related Macular Degeneration in Europe: The Past and the Future" Ophthalmology. 124(12): 1753-1763.

Pentek M., Brodszky V., Biro Z., Kolkedi Z., Dunai A., Nemeth J., Baji P., Rencz F., Gulacsi L. Resch M. D. (2017): "Subjective health expectations of patients with age-related macular degeneration treated with antiVEGF drugs" BMC Geriatr. 17(1): 233.

Dorner T., Strand V., Cornes P., Goncalves J., Gulacsi L., Kay J., Kvien T. K., Smolen J., Tanaka Y. Burmester G. R. (2016): “The changing landscape of biosimilars in rheumatology" Ann Rheum Dis. 75(6): 974-982.

Gulacsi L., Rencz F., Poor G., Szekanecz Z., Brodszky V., Baji P. Pentek M. (2016): “Patients' access to biological therapy in chronic inflammatory conditions; per capita GDP does not explain the intercountry differences" Ann Rheum Dis. 75(5): 942-943.

Kiss C., Lövei C., Sütő G. Czirják L. (2005): "Prevalence of rheumatoid arthritis in the SouthTransdanubian region of Hungary based on a representative survey of 10,000 inhabitants." Journal of Rheumatology, (Oxford). 32): 1688-1690.

Lepp-Gazdag A., Gulácsi L., Brandtmüller Á. Dávid T. (2002): "A rheumatoid arthritis megbetegedés és ellátás jellemzői Magyarországon” Egészségügyi Gazdasági Szemle. 6): 645-657.

Hernlund E., Svedbom A., Ivergård M., Compston J., Cooper C., Stenmark J., McCloskey E. V., Jönsson B. Kanis J. A. (2013): "Osteoporosis in the European Union: medical management, epidemiology and economic burden: A report prepared in collaboration with the International Osteoporosis Foundation (IOF) and the European Federation of Pharmaceutical Industry Associations (EFPIA)" Archives of Osteoporosis. 8(1-2): 136.

Raspe A., Matthis C., Scheidt-Nave C. Raspe H. (1998): "European Study of Vertebral Osteoporosis (EVOS): design and implementation in 8 German study centers" Med Klin (Munich). 93 Suppl 2(12-16,18.

OEP (2013): Osteroporosis következtében nökben kialakuló csonttörés primer prevenciójának finanszirozási protokolja (eljárásrend). http://www.neak.gov.hu/data/cms989744/0626_ osteoporosis_primer_prevencio_finanszirozasi_protokoll.pdf. Lekérdezve: 2018. 03. 13.

EMMI (2017): Az Emberi Eröforrások Minisztériuma szakmai irányelve az epilepsziás rohamok és epilepszia felismeréséröl, kezeléséről és az epilepsziás betegek gondozásáról. http://www.hbcs. hu/uploads/jogszabaly/2482/fajlok/epilepszia\%20.pdf. Lekérdezve: 2018. 03. 12.

OEP (2013): A Parkinson betegségcsoport diagnosztikájának és kezelésének finanszírozási eljárásrendje (eljárásrend). http://www.neak.gov.hu/data/cms989733/0626_parkinson_ finanszirozasi_protokollja.pdf. Lekérdezve: 2018. 03. 13.

Olesen J., Gustavsson A., Svensson M., Wittchen H. U. Jonsson B. (2012): "The economic cost of brain disorders in Europe" Eur J Neurol. 19(1): 155-162.

OEP (2010): A szkizofrénia antipszichotikus gyógyszeres kezelése A finanszírozási protokoll háttéranyaga http://site.oep.hu/prot2/25_A_szkizofrenia_antipszichotikus_gyogyszeres_ kezelese_finanszirozasi_protokoll_hatteranyag.pdf. Lekérdezve: 2018. 03.13.

OEP (2010): A sclerosis multiplex diagnosztikája és kezelése A finanszírozási protokoll háttéranyaga http://site.oep.hu/prot2/23_A_sclerosis_multiplex_diagnosztikaja_es_kezelese_ finanszirozasi_protokoll_hatteranyag.pdf. Lekérdezve: 2018.03.13. 
KSH (2009): Európai lakossági egészségfelmérés. https://www.ksh.hu/elef/archiv/2009/kal_kopp. html. Lekérdezve: 2018. 04. 10.

OECD (2017): Health at a Glance 2017. https://www.oecd-ilibrary.org/content/publication/ health_glance-2017-en. Lekérdezve: 2017. 12. 08.

Krol M., Papenburg J. van Exel J. (2015): "Does including informal care in economic evaluations matter? A systematic review of inclusion and impact of informal care in cost-effectiveness studies" Pharmacoeconomics. 33(2): 123-135. 